\title{
Measles Morbidity and Mortality Trend in Nigeria: A 10-Year Hospital-Based Retrospective Study in Lagos State, Nigeria
}

\author{
Akeeb O. Bola Oyefolu¹, Olufunmilayafo G. Oyero², Azeez A. Anjorin1, Olumuyiwa B. Salu³, \\ Kabir' O. Akinyemi', Sunday A. Omilabu ${ }^{3}$
${ }^{1}$ Department of Microbiology, Lagos State University (LASU), Badagry Expressway Ojo. PO Box 10210 LASU, Ojo, Lagos, Nigeria
${ }^{2}$ Institute for Advanced Medical Research and Training, College of Medicine, University of Ibadan, Ibadan, Nigeria
${ }^{3}$ Virology Research Laboratory, Department of Medical Microbiology and Parasitology College of Medicine, University of Lagos, Idi-Araba, P.M.B. 12003, Lagos, Nigeria

\begin{abstract}
Objective: This hospital-based retrospective cohort study was undertaken with a view to determine the epidemiological trend of measles in Lagos State, Nigeria

Methods: Medical records of clinically diagnosed measles patients from nine referral public hospitals in Lagos State between 1998 and 2007 were retrieved, transcribed and reviewed. Data were analyzed using standard methods.

Results: A total of 35,500 clinically confirmed cases and 835 deaths (case fatality rate $=2.35 \% / 10$ years) were recorded. The mean incidence was estimated at 19 cases per 100,000 population/year. A consistent seasonality pattern of measles was observed for the study period. The under-fives accounted for the highest reported cases (76.30\%) while, the under-1 year recorded highest mortality (53.8\%). Notable shift of measles vulnerability from under-1year to under-fives was observed. Although there was significant difference between cases and deaths among the age groups $(p<0.05)$, no difference was observed in measles annual occurrences among the years under review and genders $(p>0.05)$.
\end{abstract}

Conclusion: This study recorded high incidence and case fatality of measles, which poses serious public health threat. Poor demographic data collection and storage were revealed thus, computerization of medical records for collection, storage and retrieval of data is imperative for adequate planning and control of measles imperil in Nigeria. J Microbiol Infect Dis 2016;6(1): 12-18

Key words: Measles, morbidity, mortality, seasonality, retrospective.

\section{Nijerya'da Kızamık Mortalite ve Morbiditesinin Eğilimi: Lagos Eyaletinde 10-Yıllık Hastaneye Dayalı Retrospektif Bir Çalışma}

\section{ÖZET}

Amaç: Bu hastaneye dayalı retrospektif kohort çalışma Nijerya'nın Lagos Eyaletinde kızamığın epidemiyolojik eğilimini göstermek amacıyla yapıldı.

Yöntemler: Lagos Eyaletinde referans hastane konumundaki dokuz kamu hastanesinin 1998 ile 2007 yılları arasındaki kayıtlarından klinik olarak kızamık tanıı konulan hastaların verileri toplandı, kaydedildi ve değerlendirildi. Veriler standart metotlarla analiz edildi.

Bulgular: Toplam olarak 35500 klinik olarak doğrulanmış vaka ve 835 ölüm kaydedildi (vaka ölüm hızı = \% 2,35/10 yıl). Ortalama kızamık insidansı 100,000 kişi/yıl için 19 vaka olarak belirlendi. Çalışma süresince kızamık için tutarlı bir mevsimsel model olduğu gözlendi. Beş yaş altındakiler en fazla rapor edilen grup olurken (\% 76,3), bir yaş altındakiler en fazla mortalite görülen gruptu (\% 53,8). Kızamık duyarlılı̆ındaki 1 yaş altındaki gruptan 5 yaş altındaki gruba dikkate değer bir kaymanın olduğu dikkat çekti. Yaş grupları arasında olgular ve ölümler açısından anlamlı farkılıklar vardı $(p<0.05)$, ancak çalışmanın yapıldığı yıllar arasında yaş ve cinsiyet açısından bir farklılık oluşmadı ( $p>0.05)$.

Sonuç: Bu çalışma kızamığın halk sağlığına ciddi bir tehdit oluşturan yüksek insidans ve vaka ölüm hızına sahip olduğunu gösterdi. Demografik verileri toplama ve kaydetmedeki yetersizlikler, medical kayıtların kaydedilmesinin, toplanmasının ve tekrar değerlendirme için hazırlanmasının kompitürize edilmesinin Nijerya'da kızamık tehlikesine karşı yeterli planlama ve kontrol için bir zorunluluk olduğunu gösterdi.

Anahtar kelimeler: Kızamık, morbidite, mortalite, mevsimsellik, retrospektif

Correspondence: Akeeb O. Bola Oyefolu, Department of Microbiology, Lagos State University (LASU),

Badagry Expressway Ojo. PO Box 10210 LASU, Ojo, Lagos, Nigeria, Email: akeeb.oyefolu@lasu.edu.ng

Received: 18 June 2015, Accepted: 25 October 2015

Copyright (C) Journal of Microbiology and Infectious Diseases 2016, All rights reserved 


\section{INTRODUCTION}

Measles, a highly contagious disease still remain endemic with devastating effect and causing high morbidity and mortality among young children in developing countries, despite the availability of a safe and effective vaccine [1]. It is estimated that, of the 80 million children born annually in the developing world, about 5 million die and about the same number end up crippled, blind, mentally retarded or otherwise disabled as a result of vaccine-preventable diseases [2].

Mass immunization campaigns with the liveattenuated measles vaccines have substantially reduced the cases of measles death. The joint $\mathrm{WHO} /$ UNICEF 2001 measles mortality reduction plan focuses on 45 priority countries that account for almost $95 \%$ of global measles deaths [3]. With support from the Measles Partnership, a consortium of not-for-profit and UN-based organizations, African region countries have made outstanding progress towards the World Health Assembly goal of a $50 \%$ reduction in mortality worldwide [4]. Although vaccination coverage has remained low in some African countries, the region recorded an estimated $60 \%$ reduction in measles mortality from the 1999 baseline level of 500,000 to 200,000 in 2004 [5].

According to $\mathrm{WHO}$ estimates in 2000 , measles accounted for approximately 777,000 deaths worldwide, of which around $60 \%$ occurred in sub-Saharan Africa with Nigeria in particular accounting for a substantial part of the burden. The number of cases reported to WHO/UNICEF dropped from 520,000 in the year 2000 to 316,000 in 2005 [4]. In 1980s, before widespread vaccination, measles caused an estimated 2.6 million deaths each year but in recent years, global mortality have decreased by $78 \%$; from 562,000 deaths in the year 2000 to 122,000 in 2012 [1,6]. Although the regional objectives have not yet been achieved, the recorded success suggests that considerable progress has been made in reducing measles regional mortality [5].

Despite this regional and global concerted progress however, measles still account for the highest $(50 \%)$ mortality among the six vaccine-preventable diseases under the WHO-EPI [7]. Indeed globally, estimated 30-40 million cases still occur annually with the overwhelming majority ( $>95 \%)$ of deaths occurring in countries with low per capita incomes and weak health infrastructures [6,7]. Although measles morbidity and mortality patterns tend to differ between continents and geographic locations even within regions of the same country, many de- veloped countries such as the Americas have however made considerable progress towards measles control $[8,9]$.

Poor vital registration and under-reporting of cases complicate strategic planning of disease control program in Nigeria. The changing patterns of measles epidemiology in most African countries including Nigeria therefore, require new data to show the morbidity and mortality trend for future strategic planning. With a view to determine the current epidemiological trend of measles, its incidence and case fatality rate, we conducted a 10-year hospitalbased retrospective investigation in major urban and suburban healthcare facilities in Lagos State, Nigeria.

\section{METHODS}

Ethical approval and permission: Permissions were sought and given by both the Lagos State Ministry of Health (LSMOH) and Lagos State Health Services Commission (LSHSC) while the ethical approval was obtained from the Ethical Committee of the College of Medicine, University of Lagos, Idi-Araba, Lagos, Nigeria.

Study centers and Subjects: A 10-year retrospective cohort study on measles morbidity and mortality was conducted in Lagos State, Nigeria between January 1998 and December 2007. Upon written approval by the LSMH and LSHMB, nine prominent referral public hospitals across the Lagos State were visited and used as the study centers [9]. These hospitals were categorized into two:

a. Urban Referral Hospitals: Gbagada General Hospital (GGH), Isolo General Hospital (ISGH), Mainland General Hospital (MGH) (formerly called Infectious Diseases Hospital, IDH), Ikeja General Hospital (KJGH) and Massey Street Children Hospital (MSCH).

b. Sub-Urban Referral Hospitals: Badagry General Hospital (BGH), Epe General Hospital (EGH), Ajeromi General Hospital (AGH), Ikorodu General Hospital (KRGH).

The hospitals served as referral centres for both in-patients and outpatients in the various communities under the respective Local Government Areas (LGAs) of the State. Patients brought to these hospitals cut across all socio-economic classes of the population. Thereafter, medical records of clinically diagnosed patients with confirmed measles cases for the 10-year period were retrieved, transcribed and reviewed for analysis. 
Case definition and Confirmation: Measles case was defined as patient characterised with prodromal fever $\left(39^{\circ} \mathrm{C}-41^{\circ} \mathrm{C}\right)$, generalized maculopapular rash appearing on the face between the 3rd and 7 th day from the onset of the disease, lasting $4-7$ days with at least one of: conjunctivitis, coryza, croup and pathognomonic Koplik's spots on the buccal mucous membrane. Clinically suspected measles cases were further confirmed routinely by the various hospital laboratories using measles IgM ELISA kit.

Data collection: Records of documented confirmed measles cases were transcribed. Important demographic data such as; name, address, sex, age, nationality, symptoms, complications and mortality of all measles patients on record for the 10year reviewed period were collected from the visited referral hospitals in Lagos State. As at the time of this study, the estimated population of Lagos State according to Lagos State Bureau of Statistics was 19 million. Vaccination history and travel records were found not documented in all the referral hospitals under review. The established system of each hospital's record keeping, staff compliance and inadequacies in data collection, storage and retrieval were also noted.

Data Analysis: All transcribed data were subjected to full statistical analysis using the computer
Software "Statistica for Windows, Version 5.0, (C) STAT Soft Inc., USA. Analysis of variance (ANOVA) was performed to assess statistical significance between groups (sexes, age, hospitals, months of incidence and year), using the "Kruskal-Wallis Test" while multiple comparative test of significance in measles cases and deaths between the different hospitals was done with "Tukey's Test"

\section{RESULTS}

Out of the 35,500 clinically confirmed cases of measles for the 10year period, 835 deaths were recorded (case fatality $=2.35 \% / 10$ years). The mean incidence for the study period was estimated at 19 cases per 100,000 population/year. This translated to 0.45 deaths per every 19 reported cases per year/100,000 population. The absolute numbers of deaths declined as cases reduced; unfortunately, case fatality rates did not improve for the study period (Figure 1). There was however no statistical significant difference between male and female in cases and fatalities $(p>0.05)$ for the 10-year period. Furthermore, the overall number of reported cases in all the hospitals was marginally higher for males than females (Figure 1).

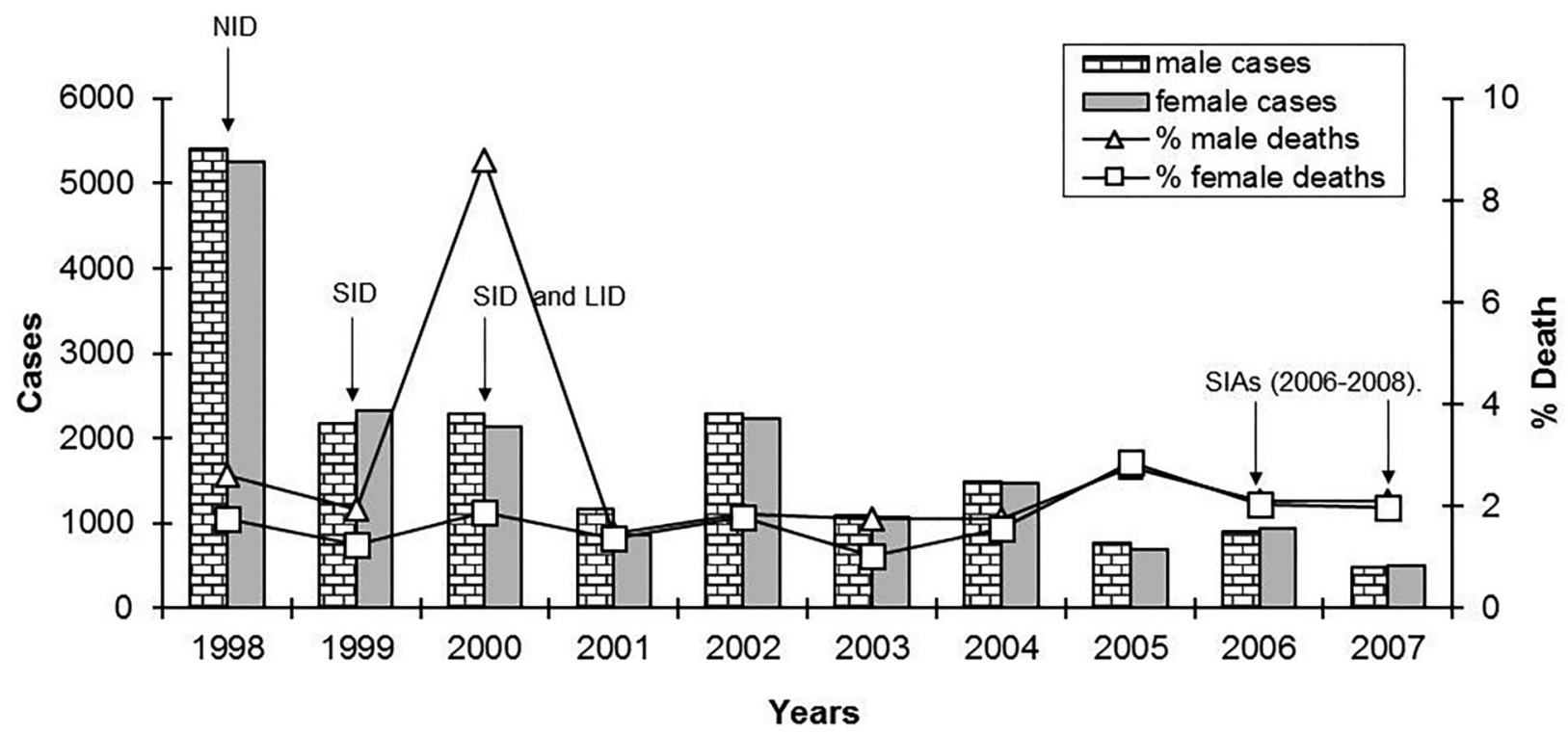

Figure 1. Reported Measles Cases and Deaths by Year and Gender in Lagos State, Nigeria (1998 - 2007$)$

NID=National Immunization Day, SID = State Immunization Day

LID=Local Immunization Day, SIAs = Supplementary Immunization Activities 


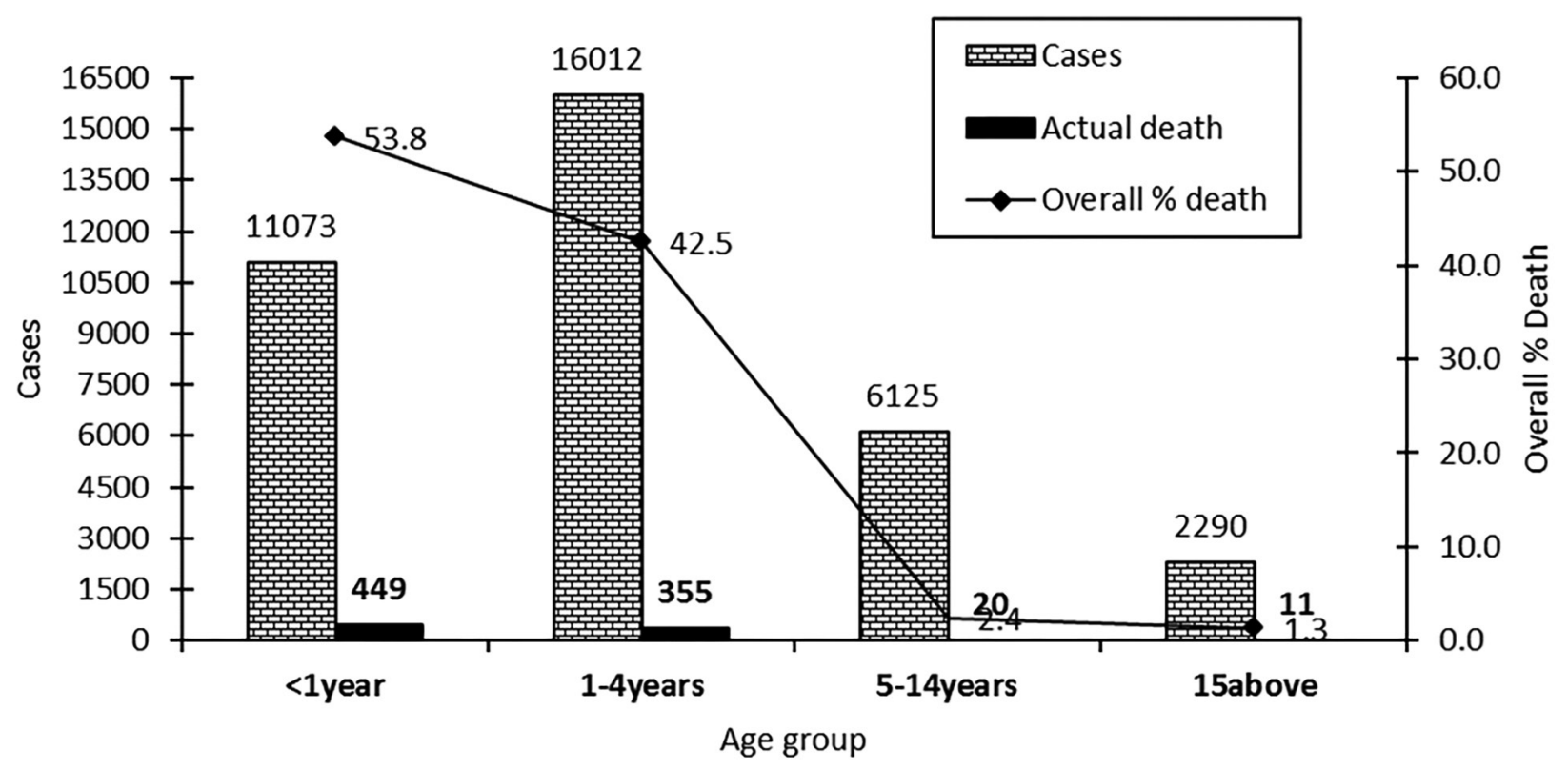

Figure 2. Reported Measles Morbidity and Mortality by Age in Lagos State, Nigeria (1998 - 2007).

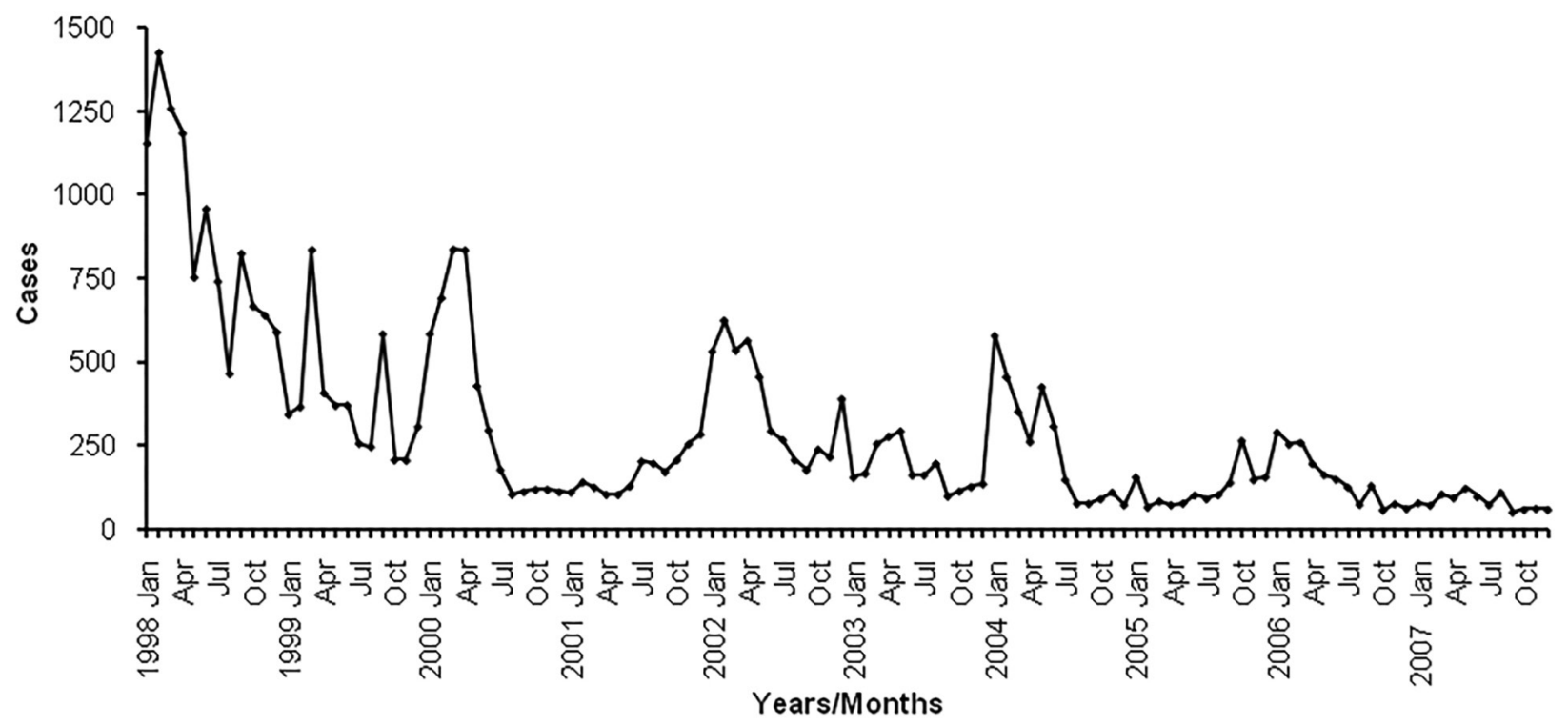

Figure 3. Seasonality pattern of Measles in Lagos State, Nigeria (1998 - 2007).

This study revealed that the under-five years of age accounted for $76.30 \%$, while patients above 5 years accounted for $23.70 \%$ of the entire cases. The highest mortality (449/11073) was recorded among the under 1-year age group (Figure 2). The ratio of each group death to the total group deaths was calculated as the overall percentage death in the various age groups studied. This showed that, the age group 1-4years had the highest reported cases $(45.1 \%)$ while; the highest death (53.8\%) was recorded among the under-1 years of age for the study period (Figure 2). However, there was statistical significant difference between the reported number of cases and deaths among the various age groups $(p<0.05)$. The overall case fatality was also found to be declining as the age increases (Figure 2). 
The urban referral hospitals $(\mathrm{GGH}$, ISGH, $\mathrm{MGH}, \mathrm{KJGH}$ and $\mathrm{MSCH}$ ) accounted for $59.31 \%$ of the reported cases with case fatality ranging between 0.23 and $5.46 \%$ while, the suburban ones
( $\mathrm{AGH}, \mathrm{BGH}, \mathrm{EGH}$ and $\mathrm{KRGH})$ accounted for the remaining $40.69 \%$ with fatality rate between 0.0 and $0.95 \%$ (Table 1).

Table 1. Reported Measles Morbidity and Mortality for 10-year period (1998-2007) in Lagos State Public Hospitals, Nigeria.

\begin{tabular}{|c|c|c|c|c|c|c|c|}
\hline \multirow{2}{*}{ Hospitals } & \multicolumn{2}{|c|}{ Cases } & \multicolumn{2}{|c|}{ Deaths } & \multicolumn{2}{|c|}{ Total } & \multirow{2}{*}{$\begin{array}{c}\text { Case Fatality } \\
\text { Rate (\%) }\end{array}$} \\
\hline & Male (\%) & Female (\%) & Male (\%) & Female (\%) & Cases (\%) & Deaths (\%) & \\
\hline $\mathrm{BGH}$ & $4,298(49.0)$ & $4,472(51.0)$ & $68(81.9)$ & $15(18.1)$ & $8,770(24.7)$ & $83(9.9)$ & 0.95 \\
\hline EGH & $2,081(48.1)$ & 2,246 (51.9) & $0(0.0)$ & $0(0.0)$ & $4,327(12.2)$ & $0(0.0)$ & 0.00 \\
\hline GGH & $639(49.7)$ & $647(50.3)$ & $2(66.7)$ & $1(33.3)$ & $1,286(3.6)$ & $3(0.4)$ & 0.23 \\
\hline AGH & 442 (46.6) & 507 (53.4) & $0(0.0)$ & $0(0.0)$ & $949(2.7)$ & $0(0.0)$ & 0.00 \\
\hline ISGH & $230(49.7)$ & $233(50.3)$ & $5(29.4)$ & $12(70.6)$ & $463(1.3)$ & $17(2.0)$ & 3.67 \\
\hline KRGH & 255 (63.8) & $145(36.3)$ & $0(0.0)$ & $0(0.0)$ & $400(1.1)$ & $0(0.0)$ & 0.00 \\
\hline MGH & $4,275(51.6)$ & 4,002 (48.4) & $191(83.0)$ & $39(17.0)$ & 8,277 (23.3) & $230(27.5)$ & 2.78 \\
\hline $\mathrm{KJGH}$ & $4,345(52.6)$ & 3,917 (47.4) & $191(54.4)$ & $160(45.6)$ & $8,262(23.3)$ & 351 (42.0) & 4.25 \\
\hline $\mathrm{MSCH}$ & $1,456(52.6)$ & $1,310(47.4)$ & $82(54.3)$ & $69(45.7)$ & $2,766(7.8)$ & $151(18.1)$ & 5.46 \\
\hline TOTAL & $18,021(50.8)$ & $17,479(49.2)$ & $539(64.6)$ & $296(35.4)$ & $35,500(100.0)$ & $835(100.0)$ & 2.35 \\
\hline
\end{tabular}

Generally, measles cases were recorded throughout the year for the study period with peak incidence observed between the month of August and the dusty/humid month of April. This was followed by a rapid decline during the rainy months of May to July (Figure 3). Although there was a periodic upsurge of cases observed every 2 years, there was no statistically significant difference $(p>0.05)$ between the annual occurrences among the years under study (Figure 3).

\section{DISCUSSION}

Surveillance to assess the burden of disease and guide vaccination policy remains critical for measles eradication plan. In this study, a total of 35,500 measles cases with 835 deaths were recorded (case fatality rate, CFR $=2.35 \% / 10$ years). The mean incidence was estimated at 19 cases per 100,000 population/year, translating to 0.45 deaths per every 19 reported measles cases per year/100,000 population. The incidence and the CFR as observed in this study are high however, it is in concomitance with the documented $\mathrm{WHO}$ records on Nigeria for the years 2008 and 2010 and other African countries like Malawi, Lesotho and Zambia $[10,12]$.

Our observations in this study further reiterate that measles, although virtually forgotten in the Americas, [9] is still a problem in Nigeria. This study showed that the implementation of National, State and Local Immunization Days (NIDs, SIDs, LIDs) in 1998, 1999 and 2000 respectively as well as the supplementary immunization activities (SIAs) between 2006-2008 in Nigeria, seems to have numerical reduction in measles cases and death (Figure 1). However, there was no significant impact on the morbidity and case fatality reduction for the 10-year period $(p>0.05)$. Similar observation was also reported in another parallel study by Kremer et al., that the various SIAs have so far had no significant effect in the interruption of the circulating measles virus strains in Nigeria [13]. This may account for the likely accumulation of children susceptible to measles and its resurgence which has hitherto being a major setback to measles eradication in $\mathrm{Ni}$ geria.

The ratio of each group death, to the total group deaths was calculated as the overall percentage death in the various age groups studied. This showed that, the age group 1-4years had the highest reported cases $(45.1 \%)$ while; the highest death $(53.8 \%)$ was recorded among the under-1 years of age for the study period (Figure 2). Moreover, the incidence, severity and fatality of cases as observed in this study also reduce as the age increases (Figure 2).

It is however unclear to state whether our study population is vaccinated, unvaccinated or mixed 
since it was not indicated in the transcribed hospital records. Studies have demonstrated that vaccination programs shifts disease burden out of the age group with the highest case fatality [14]. The high fatality observed among the under-1 year of age in this study may be adduced to the immature cell-mediated immune response of these young infants as reported by previous workers [15], and which often render them more prone to the fatal and life-threatening measles complications. The notable shift of measles vulnerability towards the under-five (age group 1-4years) from under-1year as observed in this study could be the expected consequence of moderately high but non-sustained vaccination coverage of various Nigerian immunization programs whose primary target age group has been one-year (specifically 9 months). However, the under 1-year children that missed the vaccination opportunity are left unprotected and vulnerable to measles thereby, constituting the high-risk population quadrant for the disease dissemination at older age whom the disease tend to shift. The introduction of the second dose policy for measles vaccination as previously suggested by Oyefolu et al [16], in another separate study may not be a misplaced priority towards stemming measles in Nigeria.

The overall number of reported cases for the study period was marginally higher for males than females in all the public hospitals (Table 1) but, there was no statistical significant difference in genders $(p>0.05)$ suggesting that there was no gender discrimination and girls were not denied basic medical care as observed by workers elsewhere [17]. Although vitamin A supplementation, nutritional status and access to health care have been identified to play important role in stemming measles morbidity rate in developing countries [14], there was no record regarding the nutritional status of the subjects from any of the hospitals under review. This observation calls for concern as it may allow the possibility of erroneous exclusion of undernourished integral part of the population that require vitamin $\mathrm{A}$ supplementation as recommended by WHO [18].

Measles cases were found to occur all through the months of the years for the 10-year period with peak incidence in the months of August and April (Figure 3). These months are known to be dusty and humid in southwest, Nigeria. Although, a periodic upsurge of measles was observed every 2 years, there was however no significant difference $(p>0.05)$ between the annual occurrences among the years under investigation (Figure 3 ).
In this study, the CFR recorded for the urban referral hospitals was 3.57 as compared to 0.57 recorded for the sub-urban referral hospitals. The sharp difference in the CFR may be attributed to the fact that the rural and the suburban communities visit hospitals only when measles complications are exacerbated, scary and life threatening [19], and could probably explain the reason for the low CFR recorded at the suburban hospitals despite their high documented morbidity (Table 1). It was however observed that, $\mathrm{MSCH}$ had the highest CFR of 5.46 among the urban referral hospitals (Table 1). This may be because MSCH is the only referral children hospital in Lagos State where most of the complicated scary measles cases ended up. Generally, there was significant difference between the CFR at the urban and the suburban hospitals $(p<0.05)$ Similar observation has been reported in another separate retrospective cohort study in these hospitals [20]

The 10-year hospital record surveillance further indicated that measles is still endemic in this part of the world. Vital demographic data such as nutritional status, vaccination and travel history were completely not available in all the transcribed hospital records thus, limiting this study from assessing the vaccine efficacy and its effectiveness among the subjects studied.

Funding for the computerization of medical records in Nigerian hospitals has become imperative for proper keeping and retrieval. The re-orientation through training and re-training of hospital health workers, medical record officers and their managements towards the importance of proper and detailed record keeping (using computers) will in no small measure contribute positively to systematic data collection, storage and retrieval for epidemiological studies of vaccine preventable diseases in Nigeria. Health education at community level, vaccine check-up and potency monitoring with reenforced publicity and jingles at the various levels of Nigeria health system are essential factors that needs immediate consideration.

This study recorded high incidence and case fatality for measles, which poses serious public health threat in Nigeria. The information from this study will provide adequate knowledge that will assist the health authorities and policy makers in proper planning, prevention and control of measles in Nigeria. Further elaborate population-based studies are still needed to redirect health authorities in targeting control programs with a view to reduce 
complications and case fatality rate as well as ameliorating measles imperil among Nigerian children in the nearest future.

\section{Acknowledgements}

We particularly appreciate the Lagos State Ministry of Health (LSMOH), Medical Director of Lagos State Hospital Services Commission (LSHSC) for the approval given without which this study may not have been possible. The entire member of staff and the Management of each of the General Hospitals visited are acknowledged for their unrivalled co-operations throughout the period of data retrieval and transfer.

Conflict of interest: The authors hereby declare no conflict of interest.

Declaration of Conflicting Interests: No conflict of interest of any author exists.

Financial Disclosure: The authors declared no financial support.

\section{REFERENCES}

1. World Health Organization. Measles Fact sheet No. 286. WHO Media Centre. Updated February 2014. http://www.who.int/ mediacentre/factsheets/fs286/en/. Accessed June 12,2014.

2. Okonko IO, Nkang AO, Udeze AO, et al. Global eradication of measles: a highly contagious and vaccine preventable disease-what went wrong in Africa? J Cell Anim Biol. 2009;3:119-140.

3. WHO/UNICEF. Review of National Immunization Coverage 1980-2001: Nigeria. WHO/UNICEF 2002:1-7.

4. Wolfson LJ, Strebel PM, Gacic-Dobo M, et al. Has the 2005 measles mortality reduction goal been achieved? A natural history modelling study. Lancet. 2007;369:191-200.

5. Arevshatiana L, Clementsb CJ, Lwangac SK, et al. An evaluation of infant immunization in Africa: is a transformation in progress? WHO Bull 2007;85:421-500.

6. World Health Organization. Immunization, Vaccines and Biologicals: Measles. 2014. Available at http://www.who.int/immunization/diseases/measles/en/. Accessed June. 12,2014.
7. Drain PK. Vaccine Preventable Diseases and Immunization Programs. Global Health Education Consortium (GHEC): World Health organization (WHO). 2012: 2004 Global Immunization data.

8. Kremer JR and Muller CP. Molecular epidemiology of measles in Asia. Curr Topics in Virol. 2003;3:169-181.

9. CDC. Progress toward interrupting indigenous measles transmission-regions of America, January 1999-September 2000. MMWR. 2000;49:986-990.

10. World Health Organization. Measles outbreaks and progress towards meeting measles pre-elimination goals: WHO African Region, 2009-2010. Weekly Epidemiological Record. 2011;86:129-140.

11. World Health Organization. Reported measles cases and incidence rates by WHO member states 2010 and 2011. WHO factsheet 2011. Available at: http://www.who.int/immunization_monitoring/diseases/measlesreportedcasesbycountry. pdf.

12. CDC. Measles outbreaks and progress toward measles pre-elimination - African region, 2009-2010. MMWR. 2011;60:374-378.

13. Kremer JR, Nkwembe E, Oyefolu AOB, et al. Measles Virus strain diversity, Nigeria and Democratic Republic of the Congo. Emerg Infect Dis. 2010;16:1724-1730.

14. Moss WJ. Measles still has a devastating impact on unvaccinated populations. PLoS Med. 2007;4:e24.

15. Berggren KL, Tharp M, Boyer KM. Vaccine-associated wildtype measles. Pediatr. Dermatol. 2005;22:130-132.

16. Oyefolu AO, Omilabu SA, Durosinmi AT, et al. Levels of measles $\mathrm{HI}$-antibody in unvaccinated children in LILG Lagos, Nigeria. J Nigerian Infect Control Assoc. 1999;2:31-34.

17. Rammohan A, Awofeso N, Iqbal K. Gender-differentials in the timing of measles vaccination in rural India. Demographic Research. 2014;30:1825-1848.

18. World Health Organization. Vitamin A supplementation to improve treatment outcomes among children diagnosed with respiratory infections. e-Library of Evidence for Nutrition Actions (eLENA) - Biological, behavioural and contextual rationale. April 2011. Available at http://www.who.int/elena/ titles/bbc/vitamina_pneumonia_children/en/. Accessed July. 13,2014 .

19. Oyefolu AO, Omilabu SA, Akinyemi KO, et al. Measles resurgence in Nigeria: a review on the attributable factors. Nigerian J Res Rev Scien. 2001;2:33-45.

20. Akinyemi KO, Osundare YO, Oyeyinka OG, Coker AO. A retrospective study of community-acquired Salmonella infections in patients attending public hospitals in Lagos, Nigeria. J Infect Dev Ctries. 2012;5:387-395. 